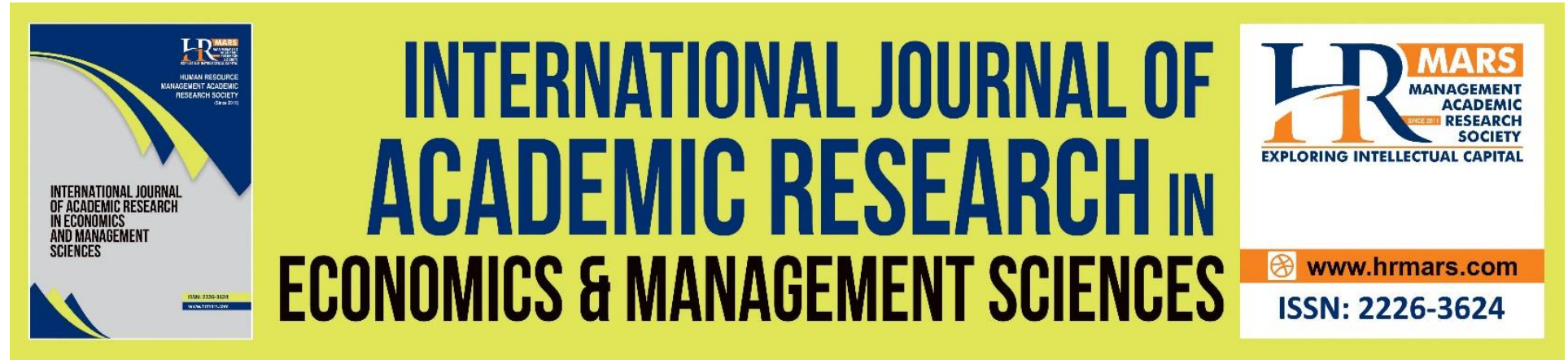

\title{
Trade Openness and Economic Growth in the Developing Countries: Evidence from Nigeria
}

\author{
Oyefabi Ilemobola Solomon, Murtala Usman Tukur
}

To Link this Article: http://dx.doi.org/10.6007/IJAREMS/v8-i3/6452

DOI: $10.6007 /$ IJAREMS/v8-i3/6452

Received: 13 August 2019, Revised: 09 September 2019, Accepted: 11 October 2019

Published Online: 27 October 2019

In-Text Citation: (Solomon \& Tukur, 2019)

To Cite this Article: Solomon, O. I., \& Tukur, M. U. (2019). Trade Openness and Economic Growth in the Developing Countries: Evidence from Nigeria. International Journal of Academic Research in Economics and Management Sciences, 8(3), 30-42.

Copyright: (c) 2019 The Author(s)

Published by Human Resource Management Academic Research Society (www.hrmars.com)

This article is published under the Creative Commons Attribution (CC BY 4.0) license. Anyone may reproduce, distribute, translate and create derivative works of this article (for both commercial and non-commercial purposes), subject to full attribution to the original publication and authors. The full terms of this license may be seen

at: http://creativecommons.org/licences/by/4.0/legalcode

Vol. 8, No. 3, 2019, Pg. 30 - 42

http://hrmars.com/index.php/pages/detail/IJAREMS

JOURNAL HOMEPAGE

Full Terms \& Conditions of access and use can be found at http://hrmars.com/index.php/pages/detail/publication-ethics 


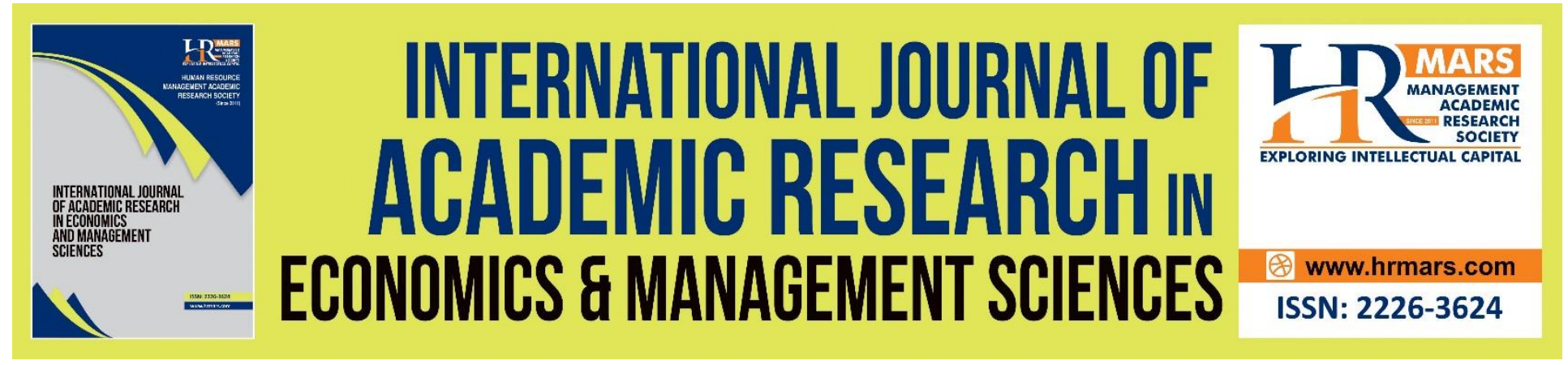

\title{
Trade Openness and Economic Growth in the Developing Countries: Evidence from Nigeria
}

\author{
Oyefabi llemobola Solomon, Murtala Usman Tukur \\ Nigerian Defence Academy, Kaduna. Nigeria \\ Email: is.oyefabi@gmail.com, tukurmurtala15@gmail.com
}

\begin{abstract}
This study purposed to examine the extent to which trade openness has impacted the growth of the Nigerian economy covering the period from 1981 to 2018. Real Gross Domestic Product (RGDP) was used as a proxy for economic growth. Other variables of interest incorporated into the model as independent variables including trade openness exchange rate and inflation. The data for the study were sourced from the Central Bank of Nigeria statistical database. The Augmented Dickey-Fuller test (ADF) was employed to ascertain the stationary of the variables, and the result revealed that the variables became stationary after the first difference. Findings from the Johansen Co-integration Test showed evidence of long-run relationship, while the Error Correction Model (ECM) revealed that trade openness has a positive and significant impact on economic growth, the ECM further revealed that inflation has a significant negative impact on economic growth while exchange rate has a positive but not significant impact on economic growth of Nigeria within the period under study. Based on the findings from the study, it was therefore recommended that the government should embark on a comprehensive trade liberalization policies and programs in order to ensure the acceleration and sustenance of the Nigerian economy.
\end{abstract}

Keywords: Trade Openness, Economic Growth, Error Correction Model, Co-integration, Nigeria

\section{Introduction}

The discussion of trade openness nexus economic growth takes its root from the fundamental economists like Adam Smith and David Ricardo who in their respective submission postulated that when countries undertake in the division of labor based on absolute advantage (Smith) and comparative advantage (Ricardo), it leads to tremendous increase in the world output. Trade openness which is all about the total or partial removal of trade barriers has become a prospective and promising idea adopted in policy making of both developed and developing economies.

The ultimate goal of trade liberalization is to enhance free trade by the removal of all trade barriers and restrictions. This is believed to promote the growth of the economy by capturing the 
static and dynamic benefits from trade through a more robust and efficient allocation of resources, healthy competition among nations, increase in the flow and exchange of technological advancement and investment, and of course, a faster pace of technological progress and capital accumulation (Ejike, Anah, \& Onwuchekwa, 2015)

Economists have a general perception of the concept of trade openness as the integration among the nations of the world where countries relate together to the extent that they have free trade, and unrestricted movement of capital and financial activities. (Echekoba, Okonkwo, \& Adigwe, 2015). Thus, trade openness can be said to be an avenue of globalization where trade, investment, finance and entrepreneurship constitute the heart.

The remarkable increased growth performance of the Asian economies (Singapore, Taiwan, Hong Kong, South Korea) over the years and growth experiences of the emerging economies of India and China was partly attributed to their early adoption of opening up their economy to foreign trade. The theoretical basis for this adoption is that trade openness is expected to enhance trade, which will, in turn, stimulate investment, thereby promoting the growth of the economy. These benefits of trade openness have stirred many developing countries in the late 1970s to adopt liberalization reforms like the reduction of import and export tariffs and non-tariff barriers.

Nigeria being a developing economy has been battling over the years with the actualization of the development process not only socially and politically but also economically. One of the earlier policies adopted in Nigeria to enhance the growth process through trade liberalization is the IMF Structural Adjustment Program (SAP) in 1986. The main objective of the SAP program was to restructure and diversify the productive base of the economy. In addition, the program was also designed to create and enhance a realistic and sustainable exchange rate system, tariff reform, liberalization, commercialization and privatization of public enterprises.

Moreover, to further actualize the trade liberalization, The Nigeria Government specifically removed import and export licensing, seventy-four (74) items on import prohibition list were reduce to 16 and also took off the eleven(11) items listed on export prohibition Meroyi, (2016). Specifically, between 1986 and 1987, there was a significant reduction of trade tariffs from an average of $33 \%$ to $23 \%$ and tariff dispersion were drastically reduced

However, despite the trade liberalization policies, the Nigeria economy still presents a typical picture of a less developed country characterized by so many economic instability and crisis. The Nigeria export performance has nothing to write about as it has performed below expectation. The country has not been able to follow other oil-producing countries like Russia, Saudi Arabia and United Arab Emirate who have been able to divert their export base. The continual dominance of the oil sector in export merchandise which account for over 70 per cent of its total earning has been a major drawback to the country's inability to fully actualize the benefit of openness trade.

There has been a considerable volume of studies carried out on the relationship between trade openness and economic growth. Evidence from different scholars and researchers shows that there is a conflict in their submissions. Some researchers are of the view that trade liberalization benefits are accrued more to the developed economies at the expense of the underdeveloped countries, therefore, asserting that it is not a good idea for developing countries to open up their fragile economy to compete in the international market because it could cripple their economic activities. (Ojeyinka \& Adegboye, 2017; Darwish, 2016). 
This study is aimed at contributing to the existing knowledge and studies by investigating both the short-run and long-run relationship between trade openness and economic growth of Nigeria. The study is structured into five (5) sections. Section one entails the introduction of the study. Section two covers the review of relevant literature on the subject matter, section three entails the methodology adopted in the study, section four presents the results and data analysis, while section five concludes and offer appropriate recommendations based on the findings from the result of the study.

\section{Literature Review}

\section{Theoretical Literature}

In order to establish the theoretical part, three of the related theories are reviewed in this study namely, Heckscher-Ohlin Model of Resources and Trade; Export-Led Growth Hypothesis; and Ricardo's Theory of Comparative Advantage.

\section{Heckscher-Ohlin Model of Resources and Trade}

This theory was propounded by Eli Heckscher and Bertil Ohlin. The theory emphasized the need for trade between two countries based on the ground that there is a relative abundance of resources among the countries. Moreover, the Heckscher-Ohlin model encourages specialization between countries, that is, a country should focus on the production of those commodities it has abundant resources and imports those commodities it has limited resources to produce. For instance, a country with vast land should specialize in agriculture since it is territory-intensive (Tebekew, 2014).

\section{The Classical Theory of Comparative Advantage}

The classical theory of comparative advantage was developed by David Ricardo in 1817 . The central plank of Ricardo's comparative advantage theory is emphasized on trade interdependence between countries in order to enhance the efficiency of labour and utilization of resources which will propel growth and development. According to this theory, there is no country that is self-sufficient enough to provide all the needed resources to stimulate economic advancement. Therefore, it is imperative for the countries to focus on those commodities which have a strong technical capacity to produce or those commodities can produce at a relatively cheaper cost. Similarly, imports goods that attract a high cost of production of goods that has less ability to produce. It is believed that going this way will provide countries with the possibility to earn higher income and growth. (Alwell, Mansi \& Vincent, 2017)

\section{Export-Led Growth Hypothesis}

The export-led growth hypothesis is based on the underlying fact that the expansion of export is one the main catalyst or facilitator for the growth in each economy. This establishes that there is a strong relationship between the performance of an economy and its level of export. This hypothesis holds that the general growth of difference does not only depend on the abundance of its labour and capital but also on the expansion of export.

This hypothesis is premised, among others, on the position of Feder (1983) who asserted that the expansion of export has the potential to create positive externalities on non-export sectors as these sectors are made to become more efficient in their resource management and 
improvement in production techniques. Moreover, Helpman and Krugman (1985) further provided more justification for the export-led growth by stating that the expansion of export will yield increased productivity and access to foreign exchange and international market.

\section{Empirical Literature}

A large number of scholarly researches works around the world have been directed towards the impact of trade openness and economic growth. Such researches have brought about various results and submissions. A time-series analysis on the impact of trade of liberalization on economic growth in Nigeria was examined by Alwell, Mansi and Vincent (2017). Findings from the Autoregressive distributed lag model revealed that trade openness has a significant and positive impact on economic growth in both the short-run and long-run period. Also, Hlalefang and Kolisi (2017) adopted the Autoregressive distributed lag model to examine the extent at which trade openness influences the economic growth of Ghana and Nigeria making use of a set of data that span from 1980 to 2016. It was concluded from their findings that, while trade openness has a positive and significant impact on the economic growth of Ghana, a Negative impact of trade openness on the economic growth of Nigeria was noticed.

Ejike, Anah, and Onwuchekwa (2015) conducted a study which was premised on the effect of trade liberalization on the economic growth of Nigeria covering a period between 1980-2015. Evidence form the Ordinary least Square revealed a positive and significant relationship between trade openness and economic growth within the sampled period. The results also presented a negation of the prior studies in the case of export and import which showed negative and positive signs respectively. Moreover, Iheanacho (2017), examined the impact of trade liberalization in the developing economies using a time series data from 1981 to 2014 . Two measures of trade liberalization were used in the study to form an index of trade openness, while three measures of financial sector development were employed to construct an index of financial development using principal component analysis. The result as presented by the Autoregressive Distributed Lag (ARDL) bound test approach revealed that trade openness has a negative and significant longrun impact on economic growth while the short-run showed evidence of a positive relationship. The result of other variables introduced in the model which are financial development, labour force and gross capital formation, showed that none of them played a significant impact on economic growth in Nigeria.

Muhammad, Rauf and Kalsoom (2013) employed the ARDL approach to ascertain the impact of openness, inflation on economic growth in Pakistan from 1970 to 2013 . Findings from the study showed the existence of the inverse relationship between inflation and openness thus validating the Romer (1993) hypothesis. It was also revealed from the study that both inflation and openness have a positive impact on the economic growth of Pakistan over the period under study. Masoud and Khalid (2017) utilised the ARDL model to investigate the relationship between trade openness and economic growth of Chine over the sampled period 1960 to 2015. The result of their study showed evidence of a positive correlation between trade openness and economic growth in the long run

Ojeyinka and Adegboye (2017) developed a simultaneous equation model to capture the joint effect of trade liberalization on agricultural and manufacturing sectors in Nigeria. Using a generalized method of moment technique They revealed that trade openness exerts a positive and significant impact on the output of the agricultural export, while a significant negative 
relationship exists between trade openness and manufacturing output in Nigeria. The study further revealed that the exchange rate has a positive but not significant impact on agricultural output while the exchange rate and inflation have a negative and significant impact on the manufacturing sector. Mishaelight and Khobai (2018) incorporated Foreign Direct Investment (FDI) and the Employment Rate (EMP) as an additional variable to form a multivariate framework in order to analyse the extent at which trade openness influences economic growth in Switzerland using annual data from 1990 to 2014. Findings from the Auto-Regressive Distributive Lag (ARDL) test revealed the existence of a long-run relationship among the variables The relationship between trade openness and economic growth of selected East Asian countries was understudied by Jin (2000) using the VAR techniques of analysis. Results from the Impulse Response Functions (IRF) and Forecast Error Variance Decomposition (FEVD) revealed that trade openness does not promote growth in the selected countries. It was further revealed from the study that fiscal and foreign policy has a positive influence on economic growth

\section{Methodology}

In order to determine the impact of trade openness on economic growth in Nigeria, the study will make use of a quantitative method of analysis by employing the Vector Error Correction Model (VECM) using the econometrics software, Eviews 11 as the tool of analysis. The justification for adopting the choice of this method was based on the preliminary test of the series which showed evidence of cointegration relationship. Following the submission by Engel and Granger, (1987), which they argued that the dynamic relationship of a series can be specified by an error correction model when one the variables are cointegrated. Moreover, the ECT is expected to have a negative sign that is statistically significant, showing that any occurrence of shock in the short-run will be corrected in the long-run

\section{Model Specification}

The model of this study is hinged on the model developed by Ojeyinka, and Adegboye (2017) in which they tried to examine the impact of openness to trade on the economic performance of Nigeria with emphases on the agricultural and manufacturing sector. However, the study takes divergence by modifying their model using the real gross domestic product as a proxy for economic performance. Thus, it is assumed that gross domestic product, which is the dependent variable, in this case, is a function of trade openness, inflation and exchange. The model is therefore specified in the following functional form

$\mathrm{RGDP}=\mathrm{f}(\mathrm{TOP}, \mathrm{EXR}, \mathrm{INF})$

Where:

RGDP $=$ Real Gross Domestic Product (Proxy for economic growth)

TOP $=$ Trade Openness, measured by the ratio of total trade (import plus export) to GDP

EXR $=$ Real Exchange Rate

INF = Inflation Rate

Specifying equation 3.1 in an explicit econometrics form, the model becomes

$\mathrm{RGDP}_{\mathrm{t}}=\lambda_{0}+\lambda_{1} \mathrm{TOP}_{\mathrm{t}}+\lambda_{2} \mathrm{EXR}_{\mathrm{t}}+\lambda_{3} \mathrm{INF}_{\mathrm{t}}+\mathrm{U}_{\mathrm{t}}$

Where $\lambda_{0}=$ Intercept

$\lambda_{1}, \lambda_{2}, \lambda_{3}=$ Coefficient/slope of the independent Variables

$\downarrow=$ White noise error term (with usual properties of zero mean and non-serial correlation). 
In a more explicit form, the models can be rewritten in a log-linear form to transform the variables into the same unit and base. Thus equation 3.2 becomes

$\operatorname{lnRGDP} P_{t}=\lambda_{0}+\lambda_{1} T_{O P}+\lambda_{2} E X R_{t}+\lambda_{3} I N F_{t}+u_{t}$

Where $\mathrm{In}=$ Natural Logarithm.

However, since the study will be making use of the Vector Error Correction Model, equation 3.3 can be specified in the following VECM model equations.

$\triangle R G D P_{t}=\varphi+\sum_{i=1}^{k-1} \quad \boldsymbol{B}_{i} \Delta \boldsymbol{R} \boldsymbol{G D} \boldsymbol{P}_{t-1}+\sum_{j=1}^{k-1} \quad \Phi_{j} \Delta T O P_{t-\jmath}+\sum_{m=1}^{k-1} \quad \alpha_{m} \Delta E X R_{t-m}+\sum_{l=1}^{k-1} \quad \delta_{n} \Delta / N F_{t-l}+$

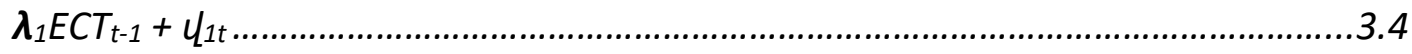

$\Delta T O P_{t}=\sigma+\sum_{i=1}^{k-1} \quad b_{i} \Delta R G D P_{t-1}+\sum_{j=1}^{k-1} \quad \boldsymbol{\Phi}_{j} \Delta T O P_{t-\jmath}+\sum_{m=1}^{k-1} \quad \alpha_{m} \Delta E X R_{t-m}+\sum_{l=1}^{k-1} \quad \delta_{n} \Delta I N F_{t-l}+$

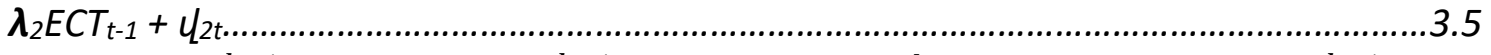

$\Delta E X R_{t}=\Phi+\sum_{i=1}^{k-1} \quad b_{i} \Delta R G D P_{t-1}+\sum_{j=1}^{k-1} \quad \Phi_{j} \Delta T O P_{t-\jmath}+\sum_{m=1}^{k-1} \quad \boldsymbol{\alpha}_{m} \Delta E X \boldsymbol{R}_{t-m}+\sum_{l=1}^{k-1} \delta_{n} \Delta / N F_{t-l}+$

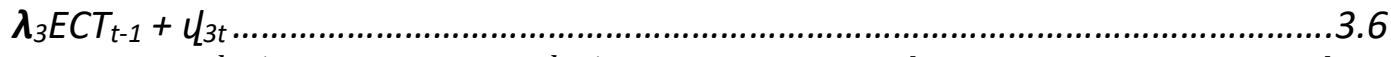

$\Delta I N F_{t}=\vartheta+\sum_{i=1}^{k-1} \quad b_{i} \Delta R G D P_{t-1}+\sum_{j=1}^{k-1} \quad \Phi_{j} \Delta T O P_{t-\jmath}+\sum_{m=1}^{k-1} \quad \alpha_{m} \Delta E X R_{t-m}+\sum_{l=1}^{k-1} \quad \boldsymbol{\delta}_{n} \Delta I N \boldsymbol{F}_{t-l}+$ $\lambda_{3} E C T_{t-1}+\varphi_{4 t}$

Where

$\Delta=$ First difference operator

k-1 = showing that the lag length is reduced by 1 since VAR is differenced to obtain a VECM, thus a lag length is lost

$\beta_{\mathrm{i}}, \Phi_{\mathrm{j}}, \alpha_{\mathrm{m}}, \delta_{\mathrm{n}}=$ Short-run dynamics coefficients of the model's adjustment long-run equilibrium

$\lambda_{1}=$ Speed of Adjustment with a negative sign

$E C T_{t-1}=$ the error correction term is the lagged value of the residual obtained from the cointegrating regression of the dependent variable on the regressor

$u_{1 t}=$ residual (stochastic error term often calls the impulses or innovations or shocks)

\section{Source of Data}

The study employs annual time series data on the real gross domestic product (RGDP), trade openness (TOP), the real exchange rate (REXR) and inflation rate (INF) from 1981 to 2018 (38 years) to the examine the relationship between trade openness and economic growth. Data for the variables were obtained from the Central Bank of Nigeria Statistical Database. This period is believed to be long enough to capture the long-run relationship between the variables under study.

\section{Analytical Techniques}

Prior to the estimation of cointegration test to establish the existence of a long-run relationship between openness to trade and economic growth in Nigeria, the stationarity status of the series will be determined by applying the Augmented Dickey-Fuller test (ADF) unit root test. The Augmented Dickey-Fuller Test (ADF) is unit root test for stationarity by Dickey and Fuller (1979), a time series is said to be stationary if its mean, variance and auto-covariance (at various lags) remain the same no matter the point at which they are measured. The unit root test is specified as thus (assuming for variable $Y$ )

$\Delta \mathrm{Y}=\mathrm{X}_{0}+\mathrm{X}_{1} \mathrm{Y}_{\mathrm{t}-1}+\Sigma \mathrm{Yi} \Delta \mathrm{Y}_{\mathrm{t}-1}+\mathrm{e}_{\mathrm{t}}$ 
Where $\Delta$ is the first difference operator, Yi are constant parameters, $e_{t}$ is a stationary stochastic process. The minimum Akaike information criterion will be used to determine the number of lags (m) for the series.

However, for the purpose of determining the order of integration of the variables, equation 3.8 is modified for the inclusion of the second differences on lagged first and $\mathrm{m}$ lags of the second differences. The equation now becomes

$\Delta^{2} Y_{t}=\mu \Delta Y_{t-1}+\Sigma \theta_{i} \Delta^{2} Y^{t-1}+e_{i t}(I=1 t \ldots ., m)$

Where $\mathrm{m}$, qi are constant parameters while $e_{i t}$ is a stationary stochastic process. The $\mathrm{m}$ lagged difference terms are included so that the error terms $e_{t}$ and $e_{i t}$ in both equations are serially independent.

After testing for the stationarity status of the variable, the cointegration test will be estimated by employing two cointegration techniques that were developed by Johansen and Juselius (JJ) (1990). In the Johansen and Juselius method, both the maximum eigenvalue test and the trace test will be used to determine the long-run relationship of the series. Evidence of cointegration will be accepted if both the Trace and Max-eigenvalue test statistics indicate one co-integrating vector at the $5 \%$ level of significance.

If the cointegration relationship is established, The Vector Error Correction Model (VECM) comes into play to enables us to evaluate the cointegrated series. However, in a situation where there is no evidence of cointegration, the Vector Autoregressive Model (VAR) will be adopted to test for the short-run causality between the variables.

\section{Analysis of Data}

\section{Test for Stationarity (Unit Root Test)}

The study commences its analysis by first testing the stationarity status of the series. The rationale behind this is to avoid the problem of spurious regression which is commonly associated with a time series data. This test is conducted using the Augmented Dickey-Fuller (ADF) Unit root test as presented in table 1

Table 1

Augmented Dickey-Fuller Unit Root Test

\begin{tabular}{llllll}
\hline Variables & ADF Stat. & Critical Value (5\%) & $\begin{array}{l}\text { Order of } \\
\text { Integration }\end{array}$ & Prob & Remarks \\
\hline RGDP & -5.594070 & -2.945842 & I (1) & 0.0000 & Stationary \\
TOP & -8.317963 & -2.945842 & $\mathrm{I}(1)$ & 0.0000 & Stationary \\
EXR & -4.211734 & -2.926622 & $\mathrm{I}(1)$ & 0.0021 & Stationary \\
INF & -5.594070 & -2.926622 & $\mathrm{I}(1)$ & 0.0000 & Stationary
\end{tabular}

Researcher's computation using Eviews 10 Software

The summary result of the ADF unit root test revealed that all the variables i.e. real gross domestic product (RGDP), trade openness (TOP), exchange rate (EXR) and inflation (INF) do not 
contain unit root test at their first difference. Evidence of this could be seen from the value of their respective ADF statistics which is less than the critical value. Moreover, additional evidence of stationary series could also be seen from the $p$-value for all variables which is less than $5 \%$ (at $5 \%$ level of significance). Therefore, going by this result, the null hypothesis of non-stationarity can be rejected.

\section{Johansen Cointegration Tests}

Having determined the unit root properties of the variables under study, the combination of two or more non-stationary variables could, however, be stationary if a common long-run relationship is shared between the variables. In such a case, these variables are said to be cointegrated. Thus, given the time series characteristics of the variables, this study further investigates by making use of the (Trace Statistics) and (Maximum Eigenvalue) using the methodology proposed by Johansen and Juselius (1990) in order to ascertain if the variables have a long-run relationship. Thus, table 2 presents a summary of the cointegration test

Table 2

Johansen Cointegration Test

\begin{tabular}{|c|c|c|c|c|c|c|c|}
\hline \multicolumn{8}{|c|}{ Hypothesiz } \\
\hline ed & & Trace & 0.05 & & Max-Eigen & 0.05 & \\
\hline $\begin{array}{l}\text { No. of } \\
\text { CE(s) }\end{array}$ & Eigenvalue & Statistic & $\begin{array}{l}\text { Critical } \\
\text { Value }\end{array}$ & Prob.** & Statistic & $\begin{array}{l}\text { Critical } \\
\text { Value }\end{array}$ & Prob.** \\
\hline None * & 0.575013 & 52.85309 & 47.85613 & 0.0158 & 30.80508 & 27.58434 & 0.0186 \\
\hline At most 1 & 0.232818 & 32.04801 & 29.79707 & 0.0259 & 29.541136 & 21.13162 & 0.0265 \\
\hline At most 2 & 0.215085 & 12.50688 & 15.49471 & 0.1342 & 8.718469 & 14.26460 & 0.3102 \\
\hline At most 3 & 0.099886 & 3.788408 & 3.841466 & 0.0516 & 3.788408 & 3.841466 & 0.0516 \\
\hline
\end{tabular}

Researcher's computation using E-views 10 Software

It can be seen from Table 2 that the result of the multivariate cointegration test by Johansen and Juselius cointegration technique reveal that both the trace statistic and the Maximum Eigenvalue statistic shows evidence of two cointegration relationship (at None and at most 1), where the values of the trace statistic and the Maximum Eigenvalue statistic is higher than their respective critical value at $5 \%$ significance level. This result conforms to the existence of a stable long-run relationship between gross domestic product, being the dependent variable and trade openness, inflation, and exchange rate being the independent variables. This result suggests that the appropriate model to be employed for the regression analysis is the VECM specification since a cointegration relationship has been established among the variables.

\section{The Vector Error Correction Model}

Since the presence of a long-run relationship has been established among the variables, the vector error correction model (VECM) was applied to show how the system adjusts to the long- 
INTERNATIONAL JOURNAL OF ACADEMIC RESEARCH IN ECONOMICS AND MANAGEMENT SCIENCES Vol. 8, No. 3, 2019, E-ISSN: 2226-3624 ㄷ 2019 HRMARS

run equilibrium implied by the co-integrating equation. The summary of the VECM result is presented in Table 3

Table 3

Summary of Regression Result: Vector Error Correction Model

Dependent Variable: $\mathrm{D}(\mathrm{GDP})$

\begin{tabular}{crlrr}
\hline & Coefficient & \multicolumn{1}{l}{ Std. Error } & t-Statistic & Prob. \\
\hline \multicolumn{1}{c}{ CointEq1 } & -0.566773 & 0.000504 & 3.342756 & 0.0194 \\
D (GDP (-1)) & 0.224753 & 0.246833 & 2.910546 & 0.0398 \\
D (TOP (-1)) & 0.230500 & 0.001323 & -3.378174 & 0.0280 \\
D (EXR (-1)) & 0.231319 & 0.000863 & 0.369341 & 0.7145 \\
D (INF (-1)) & -0.041371 & 0.001047 & 2.909122 & 0.0204 \\
$\quad$ C & 0.142243 & 0.049727 & 2.860469 & 0.0076 \\
\hline R-squared & 0.635301 & Mean dependent var & 0.186667 \\
Adjusted R-squared & 0.626185 & S.D. dependent var & 0.106904 \\
S.E. of regression & 0.089047 & Akaike info criterion & -1.848299 \\
Sum squared resid & 0.237880 & Schwarz criterion & -1.584380 \\
Log likelihood & 39.26939 & Hannan-Quinn criter. & -1.756184 \\
F-statistic & 25.54633 & Durbin-Watson stat & 1.943859 \\
Prob(F-statistic) & 0.000003 & & & \\
\hline
\end{tabular}

Researcher's computation using Eviews 10 Software

Table 3 presents a summary of the vector error correction model estimates. As required, the ECT has the expected negative sign $(-0.566773)$ and it is highly significant at $5 \%$ level since its corresponding $p$-value stands at $\mathbf{0 . 0 1 9 4}$. This result implies that the previous period deviation from the long-run equilibrium is corrected in the current period at an adjustment speed of approximately 56 per cent.

The coefficient of the past value of the real gross domestic product is 0.224753 , meaning that, the past value of RGDP has a positive impact on its present value, therefore holding other independent variables constant, a percentage increase in the past value of GDP will lead to approximately 0.22 per cent increase in its present value. The result of the p-value $(0.0398)$ is also significant since it is less than $5 \%$ (i.e. at $5 \%$ level of significant).

As expected, trade openness (TOP) has a positive coefficient of 0.230500 and it is significant at $5 \%$ level since its corresponding $p$-value stands at 0.0280 . Thus, a percentage increase in TOP will lead to approximately $0.23 \%$ increase in gross domestic product. The significant $p$-value also shows that the null hypothesis which states that trade openness does not exact a significant impact on economic growth can be rejected. Going by this result. It can be concluded that trade openness promotes economic growth. This finding conforms with around and Khalid (2017), and Ojeyinka, and Adegboye (2017) who also found a significant positive impact of trade openness 
on economic growth, while in contrast with Jin (2000) who concluded that openness to trade does not promote growth.

As indicated from the regression result, the coefficient of the exchange rate is positive, this is not in line with the a priori expectation. The result implies that a percentage increase in the exchange rate will amount to approximately 0.23 per cent increase in gross domestic product. However, the p-value stands at 0.7145 , meaning that such impact is not significant. This result agrees with Ojeyinka and Adegboye (2017) who also found that the exchange rate has a positive but not significant impact on economic growth. Moreover, the coefficient of inflation is -0.041371 . This means that in line with a priori expectation, the inflation rate has a negative impact on economic growth. Thus, holding other independent variables constant, a percentage increase in inflation will amount to about 0.04 per cent decrease in gross domestic product. Its corresponding $\mathrm{p}$-value is 0.0204 , which is less than 5 per cent (at $5 \%$ significant level). It can, therefore, be concluded that inflation has a significant negative impact on the growth of the Nigerian economy within the period under study. This result also agrees with the study carried out by Muhammad, Rauf and Kalsoom (2013) who also found that inflation has a significant negative impact on economic growth.

The Intercept of the model (C) also known as the autonomous or constant is the expected value of the independent variable, i.e. gross domestic product, when all independent variables i.e trade openness, exchange rate, and inflation equal zero. This value stands at 0.142243 and it is statistically significant at $5 \%$ level having had a p-value of 0.0076 . The means that gross domestic product, being a proxy for economic growth will have an autonomous increase of about 0.14 per cent when all the independent variable in the study equal zero

The R-squared also is known as the coefficient of determination or measure of goodness of fit explains the variation in the dependent variable which influenced by the independent variable. Since the $r$-squared is 0.635301 , it means that about 63 per cent variation in the gross domestic product can be explained by trade openness, exchange rate and inflation rate. The remaining 27 per cent can be attributed to other variables which also influence economic growth but not captured in the model. Considering the adjusted $R^{2}$ (which can be less than or equal to the $r$ squared) after considering the degrees of freedom, the adjusted $r$-squared explained about 62 per cent variability in gross domestic product. Therefore, it can still be concluded that the explanatory variables perfectly explained the behaviour of the dependent variable. Furthermore, the Durbin Watson statistics of 1.943859 confirms that the model is not spurious since it is approximately 2 . Thus, the model passes the test regarding the serial correlation.

The F-statistic is used to check the overall significance of the model. Thus, the F-statistic of the estimated model is 25.54633 with a probability F-statistic of 0.010497 . Since the probability of F-statistic is less than 0.05 (at $5 \%$ significant level), it can be concluded that the independent variables (trade openness, exchange rate and inflation) simultaneously influenced the dependent variable (gross domestic product).

\section{Diagnostic Test}

In other to ensure the reliability of the model, some diagnostic test was estimated. They include the serial correlation test, Normality test and Heteroskedasticity test 
INTERNATIONAL JOURNAL OF ACADEMIC RESEARCH IN ECONOMICS AND MANAGEMENT SCIENCES Vol. 8, No. 3, 2019, E-ISSN: 2226-3624 @ 2019 HRMARS

Table 4

Diagnostic Test

\begin{tabular}{lll}
\hline Diagnostic & \multicolumn{1}{c}{ Statistics } & Conclusion \\
\hline $\begin{array}{l}\text { VEC Residual Serial Correlation } \\
\text { LM Tests }\end{array}$ & $\mathrm{df}=(16,70.9)$ Prob.=0.1358 & No Serial Correlation \\
Jarque-Bera & $\mathrm{JB}=45.73541 \mathrm{Df}=8$ & Residual are Normally \\
& Prob. $=0.3178$ & Distributed \\
$\begin{array}{ll}\text { VEC Residual Heteroskedasticity } \\
\text { Tests (Levels and Squares) }\end{array}$ & $\mathrm{df}=100 \quad$ Prob. $=0.5435$ & No Heteroskedasticity \\
\hline
\end{tabular}

Researcher's computation using Eviews 10 Software

From the summary of the diagnostic test as presented in table 4, it is evident that the long-run model successfully passed the serial correlation test, normality test and Heteroskedasticity test. This submission is based on the fact that the respective $p$-values for the diagnostic tests are greater than 5\% (at 5\% significant level). Thus, the VECM model can be trusted and relied upon for policy modelling on trade openness nexus economic growth.

\section{Conclusion and Recommendations}

It is believed that trade openness is a catalyst for economic growth as a result of its influence in integrating the global economies and capacity in generating new and wider markets for the nations. It is against this backdrop that this study sought to explore the extent at which trade openness has impacted the growth of the Nigerian economy by adopting the Vector Error Correction Model estimation techniques for a span of 38 years (i.e. 1981-2018). Findings from the result revealed that trade openness has positively and significantly impacted the growth of the Nigerian economy over the period under study. Thus, trade openness can be considered as a vital instrument that can be used in boosting the economic growth not only in the short-run but also in the long-run. Based on the findings from the study, the researchers recommend that the government should embark on a comprehensive trade liberalization policies and programmes in order to ensure the acceleration and sustenance of the Nigerian economy. Nevertheless, the implementation of such policies should be done with adequate caution, this is because excessive trade liberalization policies could also have an adverse effect on the economy in a situation where it is used as an avenue to bring in sub-substandard and fake products into the country.

\section{References}

Alwell, N., \& Mansi, N., Vincent, M. O. (2017). Impact of trade liberalization on economic growth in Nigeria. International Journal of Social Science and Economics Invention (IJSSEI), 3(1)

Central Bank of Nigeria. (2018). Annual Reports and Statements of Account. Abuja Nigeria. Government Printing Press.

Central Bank of Nigeria. (2018). Statistical Bulletin

Dickey, D. A., \& Fuller, W. A. (1981). Likelihood Ratio Statistics for Autoregressive Time Series with a Unit Root. Econometrica: Journal of the Econometric Society, 1057-1072.

Darwish, S. (2016). The Understanding of Probability in the Iraqi Culture. International Journal of Mainstream Social Science: Vol. 5, Nos. 1-2, 11. 
INTERNATIONAL JOURNAL OF ACADEMIC RESEARCH IN ECONOMICS AND MANAGEMENT SCIENCES Vol. 8, No. 3, 2019, E-ISSN: 2226-3624 @ 2019 HRMARS

Ejike, D. C., Anah, S. A., \& Onwuchekwa, F. C. (2015). Trade Liberalization and Economic Growth in Nigeria: A Cointegration Analysis (1980-2015). Journal of Business Management

Egbulonu, K. G., \& Ezeocha, J. A. (2015).Trade Openness and Nigeria's Economic Growth (19902015). International Journal of Development and Economic Sustainability. 6(3), 1-11.

Echekoba, F. N., Okonkwo, V. I., and Adigwe, P. K. (2015). Trade Liberalization and Economic Growth: The Nigerian Experience (1971-2012)' Journal of Poverty, Investment and Development, 14, 51-72.

Engel, R. F., \& Granger., C. W. J. (1987). Co-integration and error correction: Representation, estimation, and testing. Econometrica, Volume 55(2), 251-

276. http://www.jstor.org/stable/1913236

Feder, G. (1983). Export and Economic Growth. Journal of Development Economics, 12, 59-73.]

Granger, C. W. (1969). Investigating Causal Relations by Econometric Models and Cross- Spectral Methods. Econometrica. Journal of the Econometric Society, 37(3).424-438.

Gujarati, D. N. (2004). Basic Econometrics. (4th Ed.) New York: McGraw-Hill, Inc.

Hlalefang, K. N., \& Kolisi, C. M. (2017). Long run relationship between trade openness and economic growth in Ghana and Nigeria. Munich Personal RePEc Archive, 81317.

Helpman, E., \& Krugman, P. (1985). Market Structure and Foreign Trade. Cambridge, MA: MIT Press.

Iheanacho, E. (2017). ARDL Approach to Trade Liberalisation and Economic Growth in the Developing Country: Evidence from Nigeria. An International Multi-Disciplinary Journal, Ethiopia Afrrev, 11 (2), 138-159

Johansen, and Juselius, K. (1990). "Maximum Likelihood Estimation and Inference on Cointegration with Applications to the Demand for Money". Oxford Bulletin of Economics and Statistics, 52(2), 169-210.

Mishaelight, C., \& Hlalefang K. (2018). The Impact of Trade Liberalisation on Economic Growth in Switzerland. Munich Personal RePEc Archive, 89884.

Meroyi, (2016). Trade liberalization and economic growth in Nigeria A cointegration analysis. Journal of Business, Economics and Finance, 4(3): 43-52

Muhammad, E., Muhammad, E. M., Rauf, B., \& Kalsoom, F. (2013). Openness, Inflation and Growth Relationships in Pakistan: An Application of ARDL Bounds Testing Approach. Pakistan Economic and Social Review, 51(1), 13-53

Masoud, A. K., \& Khalid, H. A. (2017). "Investigation of the Relationship between Trade Openness and Economic Growth in the Case Of China. International Journal of Research Granthaalayah, 5(7), 199-213. https://doi.org/10.5281/zenodo.836438.

Mishaelight, C., \& Hlalefang, K. (2018). The Impact of Trade Liberalisation on Economic Growth in Switzerland. Munich Personal RePEc Archive, 89884.

Ojeyinka, T. A., \& Adegboye, A. A. (2017). Trade Liberalization and Economic Performance in Nigeria: Evidence from Agricultural and Manufacturing sectors. African Journal of Economic Review, 5 (3)

Smith, A. (1776). The Wealth of Nations. New York: The Modern Library

Tebekew, W. (2014). A Panel Data Analysis for Bilateral Trade of Ethiopia and East African Community countries: The Gravity Model Approach. (Master's thesis, Addis Ababa University Addis Ababa, Ethiopia). Retrieved from

http://handle.unsw.edu.au/1959.4/44704 